\title{
The ABC's of Online Course Design According to Addie Model
}

\author{
Gürhan Durak ${ }^{1, *}$, Murat Ataizi $^{2}$ \\ ${ }^{1}$ Department of Computer Education and Instructional Technologies, Balikesir University, Turkey \\ ${ }^{2}$ Faculty of Communication, Anadolu University, Turkey
}

Copyright $(2016$ by authors, all rights reserved. Authors agree that this article remains permanently open access under the terms of the Creative Commons Attribution License 4.0 International License.

\begin{abstract}
The purpose of this study was to design the course of Programming Languages-I online, which is given on face-to-face basis at undergraduate level. It is seen in literature that there is no detailed research on the preparation of a fully-online course directly based on an instructional design model. In this respect, depending on the ADDIE design model, the most popular instructional design models, an online course was adapted in phases. Each phase of the model and on the steps in each phase were explained. The preparation of this course given via DLP lasted approximately 500 hours. Following its preparation, the pilot application was carried out with the learners taking the course of Programming Languages during summer school period. The learners used DLP in all respects, and DLP was revised and the necessary changes were made in line with the learners' views and with the results of the usability test. The study revealed that it was important to analyze all the related areas in the analysis phase of an online course design and to make the necessary decisions in the phase of design. In the dimension of distance education evaluation, since there is no precise and reliable method, the traditional evaluation methods were favored within the scope of the product evaluation of this course taught via DLP. In addition, within the scope of the process evaluation, the learners' views were determined via weekly evaluations. Establishing interaction in online courses is important to prove the live structure of the system, and this situation will help learners perceive themselves to a part of the course.
\end{abstract}

Keywords ADDIE, Instructional Design, Online Course, Programming Language

\section{Introduction}

Thanks to the renovations brought about by online learning, the educational needs of modern societies can now be met, and this has increased the demand for online learning in a wide range of areas from business industries to higher education institutions [1]. Due to the large number of learners in higher education and the economic restrictions, there has been an increase in the number of students in classrooms. When institutions fail to provide feedback and to make the necessary assessments, students tend to lose their engagement with each other as well as with their schools. Owing to these deficiencies, learners can not finish their higher education [2]. Considering all these negative developments, some universities now prefer to give certain courses online thanks to the developing Internet and computer technologies. According to Palloff and Pratt [3], universities favor online courses sometimes to attract students who do not attend regular face-to-face courses and sometimes to meet the needs of new-generation learners.

The increasing importance of online learning was also revealed by the last three annual reports of "Horizon Report". According to the report released in 2011, it was claimed that people expect to learn and study in any place at any time and that the tendencies to provide information technologies have become more autonomous [4]. The Horizon Report published in 2012 demonstrated that current learners want to access information on time without any difficulty, to reach resources easily and to receive feedback in a short time. These opportunities provided by informal learning change learners' expectations [5].

Today's learners are willing to continue their education in line with the developing technology. They are not content with the traditional methods at all, and it could be stated that they prefer to use the daily-life technological tools (computer, smart phone, tablet computer and so on) for educational purposes. They are seeking for ways of learning in their own pace of learning and in a way appropriate to their own learning styles [6]. This view was also supported by Horizon Report published in 2012. In relation to online learning, annual reports published by Babson Survey Research group, in USA revealed that the number of learners taking online courses between 2002 and 2013 increased from 1.6 to 7.1 million. In these reports, educators were asked to compare online learning with face-to-face learning 
in terms of learning outcomes between 2003 and 2014 . According to the reports, the view that online learning was more effective than face-to-face learning was supported by $57 \%$ in 2003 , while it reached $74 \%$ in 2014 [7]. With respect to long-term strategies of institutions, while the percentage of institutions that reported online learning to have a vital importance was $48,8 \%$ in 2003 , it was $70,8 \%$ at the end of 2014.

The reasons for such spread and preference of online learning throughout the world included the freedom provided for learners to take each course at any time they want, the decreasing duration of time spent on learning, the opportunities provided for learners to express their thoughts freely and to ask questions without any restriction, and the rights provided for them to select the course materials in relation to the lesson subjects [8]. Besides all, the variety of learning objects [9] and the process of transition to more individual, learner-centered and cooperative methods [10] are among the factors that increased the spread of online learning.

Despite this popularity of online applications, it is a well-known fact that there are some deficiencies in relation to online learning. These deficiencies can be summarized as follows: technical malfunctions likely to occur in online learning environments [11-13]; failure to meet learners' needs in line with their learners' own pace of learning [14]; failure to structure online learning environments in a way to prevent learners from being sluggish [11]; lack of communication between learners and between instructors and learners [11,13-15]; lack of good-quality materials appropriate to online learning, or failure to adapt traditional materials to online learning [11,14]; difficulties experienced in relation to feedback [11,12,15-17]; probable attention-distracting factors and eventual lack of motivation in learning [16].

One of the factors that hinder achieving the objectives of curricula is the unplanned organization of instructional design. In an unplanned instructional process, both instructors and learners are likely to be exposed to quite difficult situations and undesirable surprises. For a curriculum to become successful, the most important factor is to plan and design the curriculum with an appropriate method step by step [18]. In one study carried out by [19], who reported online learning to lead to ineffective results, it could be stated that one of the most important deficiencies was lack of an instructional design model appropriate to online courses.

\subsection{Related Studies}

In literature, there are a number of experimental studies and related meta-analyses compering online learning and traditional learning (For example, [20-27]. In some of these studies, no difference was found between the two methods $[20,21,23,28-36]$ while some of them reported that online learning could be as effective as and even more effective than traditional learning (For example, [22,27,37-44].
Online applications include the advantages of both synchronous and asynchronous environments, and these applications will bear better results if their negative aspects are overcome. When the related literature is examined, it is seen that there is a need for an environment which includes the two environments together. In addition, in literature, it was reported that there is no online course appropriate to the instructional design principles. The Distance Learning Platform (DLP) developed within the scope of the present study is believed to remove this deficiency in literature.

\section{Method}

\subsection{Research Model}

The present study aimed at making the undergraduate course of Programming Languages-I (given in the Department of Computer Education and Instructional Technologies) unavailable for distance education. In line with this purpose, the case study method, one of qualitative research methods, was used.

In the study, taking the design model of ADDIE as basis, the model was adapted to online application. In an online course design, following the steps of an instructional design model is important, though it causes time consumption, to overcome the problems likely to be experienced while teaching that course $[45,46]$. In the study, the ADDIE design model was applied not only because it was easily applicable, flexible and systematic but also because it allowed turning back to previous phases [47]. Each phase of the model and all the steps in each phase below were adapted to DLP.

\section{Adaptation of the Course}

This phase includes the process of transforming the course of Programming Languages-I to an online course. In the process, the online adaption of the ADDIE model was taken as basis, and the steps in related phases are presented in detail.

\subsection{Analysis}

The phase of analysis included needs analysis, analysis of learners, content analysis, technical analysis, structural analysis and analysis of the online environment.

\subsubsection{Needs Analysis}

As a result of informal interviews held both with the faculty members teaching the course of Programming Languages-I and with the learners taking this course, it was revealed that several difficulties were experienced due to traditional teaching of this course. Some of these difficulties included learners' low level of motivation in traditional learning [48,49], crowded classrooms [50], and problems due to teaching of a course like Programming Languages-I in 
class environment, which actually requires research and application. The increasing spread of online and mobile applications, learners' interest in new methods and their willingness to use these methods, and easy adaptation of the teaching method for the course of Programming Languages-I to distance learning were among the factors that led to teaching of this course online.

\subsubsection{Analysis of Learners}

It was important to conduct analysis regarding such characteristics of candidates who would use the online learning platform of DLP as gender, average academic score, their experience in programming and the type of high school they graduated from. Analysis of learners could make the course more productive and effective and increase learners' motivation [51].

\subsubsection{Content Analysis}

The curriculum of the course of Programming Languages-I to be taught via DLP was the same as that of the course given in traditional education. However, the digital sources were increased, and the current resources (lesson notes taken in previous years and so on) were transformed into digital format.

\subsubsection{Technical Analysis}

The technical equipment and software to be used by the DLP learners were listed, and the learners were supposed to own such devices as a personal computer, regular Internet connection, camera, microphone and headphones.

\subsubsection{Structural Analysis}

The course to be taught had an online structure. All the factors related to the course would be organized accordingly. The course would be structured both synchronously and asynchronously.

\subsubsection{Analysis of the Online Environment}

For the online platform of DLP, the current open-source Learning Management Systems were investigated. Among these systems, the one most appropriate to the system would be preferred.

\subsection{Design}

This is a process which includes responding to the questions of how to carry out the objectives and strategies determined in the analysis phase. According to Bilgiç [52], the quality of design could make the learning experience both boring or entertaining and meaningful or meaningless. In this respect, what is important is to make a difference by using the technology but without ignoring the priorities of education.

\subsubsection{Defining the Objectives}

It is important to understand and learn the course of Programming Languages-I in the best way since it constitutes the basis of other programming courses that learners will take later in their departments. In relation to this, the sub-objectives of this course could be mentioned as follows:

- Algorithms, introduction to C Programming, the concept of variable, understanding arithmetic and mathematical procedures

- Understanding such subjects as data types, input-output functions, formatted writing

- Discriminating between the concepts of break, continue, switch-case and control structures,

- Using the cycles correctly while authoring a program

- Authoring programs in the form of functions

- Understanding arrays and their basic features

- Designing the programs related to string statements

- Using the struct and file structure in the program

\subsubsection{Designing the Communication Factors}

In DLP, in order to allow the learners to interact with each other, with the faculty members or with the system, forums, chat modules, e-mail and special message service were added. In this respect, the purpose was to establish interaction between the content and the learner-instructor, which is found among interaction types in distance education [53]. In addition, this situation is supported with the view - the interaction and communication theory is based on - that the interaction between the learner and the instructor lies in the center of learning [54].

\subsubsection{Designing the Support Services}

One of the biggest problems in distance education is related to learners' feeling of isolation and their failure to feel themselves attached to their departments [55], and this problem is likely to lead to loss of motivation. In order to avoid this, it is important to have learners regard the system as a live structure. In this respect, in DLP, learners will be provided with support via communicative services. The faculty member will check the system regularly. Learners will constantly be supported with announcements, messages, live chat and sharings in the forum.

\subsubsection{Designing the Course Calendar and Teaching of the Course}

Since one academic term was planned to last 14 weeks according to the academic calendar, it was applied in DLP in the same way. The live courses were planned to be taught as night courses on the same days of the same courses given in traditional education. There was no restriction to access to the asynchronous part. It was accessible from any place at any time.

\subsubsection{Designing the Course Contents}

As the course of Programming Languages had been taught for years with the traditional method, for the course contents, there was a need for the digital forms of the current resources. In addition, the faculty member would search for resources 
regarding the subjects. Following this, by asking the permissions of the authors of resources (with the print feature disabled), the digital documents necessary for the course were included in the system.

\subsubsection{Designing the Technological Sub-structure}

Since online learning is a technology-based method, it is important to determine the technological sub-structure necessary for teaching. In line with this, the basic requirement was determined as follows: all the learners to use DLP were supposed to have their own personal computers and Internet connection. In addition, the learners were also required to have such tools as camera, microphone and headphones necessary for the synchronous courses. Furthermore, the add-ons and the explorer settings necessary to use the system would be made ready by the learners. Lastly, the learners would be registered to the system, and all the related information would be entered in the system.

\subsubsection{Designing the Evaluation System}

In DLP, it could be stated that there was no evaluation module. Although there were several software programs used to give online exams, the mid-term and final exams related to the course would be executed in class environment since related security was not fully provided. Moreover, the group homework assigned to the learners and their performances would also be evaluated.

\subsubsection{Designing the Online Environments}

In the phase of analysis, the current open-source learning management systems were investigated, and the free version of the learning management system of e-front was installed for several reasons such as easy installation, user-friendliness, simplicity and several necessary modules readily included.

In addition, as a result of evaluation of the softwares necessary for the synchronous teaching of the courses, the software of Adobe Connect 8.0 was preferred. The factors taken into account while selecting this software were as follows: there was no restriction in terms of the number of users; it included all the platforms like audios, visuals, and sharings; it did not require any other special software for its use; it allowed recording the lessons; and it was technically superior to other software programs.

\subsection{Development}

This was the phase of preparation of the elements determined in the design phase. It was the phase which included the preparation of the platform to be used.

\subsubsection{Preparation of DLP}

In the phase of design, for the asynchronous part of DLP, the Learning Management System of e-front was selected. This phase included installation of e-front, the configuration settings, selecting and forming the modules, and shaping its interface.
For the synchronous courses, the software called "Adobe Connect" was used. In this software, there were a number of applications such as file sharing, whiteboard application, screen mirroring, chat module, recording of lessons, visual and voiced communication, question-answer part and questionnaire.

\subsubsection{Dividing the Course into Modules and Developing These Modules}

In line with the objectives mentioned in the phase of analysis, the course was divided into modules. Each module was allocated 1 or 2 weeks. After the contents were prepared, the modules were uploaded to the system as files compatible with SCORM.

\subsubsection{Preparation of the Contents}

After designing the course resources, the contents were prepared in the phase of development. The fact the course was already being taught with traditional methods did not cause any difficulty in terms of resources. In line with this, the faculty member worked on the transfer of the resources into the virtual environment together with the other faculty members who previously taught the course. Following this the contents determined were turned into a module using the free software of Course Lab. The introduction part of each module included the "Objectives" and "How to study this subject?". Besides texts, the modules also included visual elements, question-answer part, evaluation part and resources that acted as a direct guide.

\subsubsection{Development of the Evaluation System}

In addition to the mid-term and final exams, the learners also dealt with projects and homework assigned as a group via DLP. The applications found in the forum section were used to observe the learners' interest, sharings, projects and their assignments. The learners would be provided with instant feedback to increase their motivation.

\subsection{Application}

This was the phase in which the learners started to use the DLP prepared.

\subsubsection{Introduction and Use of the System}

In the first lesson of the academic term, a computer laboratory application was carried out with the learners who would use DLP. In this application, a trial lesson was taught, and the learners participated in the lesson via the system. In addition, the learners were introduced to the DLP system, and they were informed about the equipment and software.

DLP was made up of two parts: synchronous and asynchronous. The link given to the learners allowed them to connect to the asynchronous part of the system (Learning Management System). Since the learners were previously registered to the system, they signed in the system using their user names and passwords. Following this, on the next screen, the students met various components regarding the 
course they were registered to (Programming Languages): Content, information about the course, tools, announcements, calendar activities, files shared, the board, logs, external links (YouTube), personal messages and recent comments. It was possible for the faculty member to include or exclude all these features. The learners tried the system after they were informed about these components.

\subsubsection{Supporting the Learning Environment}

In order to have the leaners feel they were not alone in the system and to increase their motivation, several precautions were taken such as updating the elements found in DLP, adding new ones and providing feedback. In the forum, the homework, resources, projects and applications were constantly updated. In addition, with tools like logs helped determine the learners' views about the system and their levels of satisfaction or dissatisfaction with the system. Similarly, with the help of the activities called 'board', the learners were provided with the latest announcements and sharings.

\subsubsection{Enrichment of the Communication Environments}

For the purpose of increasing the learners' interactions with each other, with the faculty member as well as with DLP, several tools such as messages, e-mail, announcements, special chat rooms and reminders were used via DLP.

\subsubsection{Starting the Course}

The theoretical part of the course lasted 3 hours, and the practical part lasted 2 hours. In this respect, the learners using DLP participated in the live courses two days a week. The asynchronous platform was open to use all the time. The learners were allowed to see the assignments, resources, announcements and several others. The lessons were taught on the day announced previously if there was no related obstacle. The theoretical lessons focused on all the dimensions of the subject, while the practical lessons involved sample questions and their answers related to the subject. When the learners failed to understand the subject, they were able to ask instant questions. If they did not want to interrupt the lesson of if they wanted to ask their questions verbally, they directed their questions via the question-answer part. The lessons continued until the midterm exams. Following the midterm exams, the lessons continued till the final exams.

\subsection{Evaluation}

The evaluation criteria for the course via DLP included homeworks assigned on weekly basis and opinions determined again on weekly basis.

\subsubsection{Sub-evaluation}

The learners were assigned group homework on weekly basis. This homework was announced to the learners and added to the forum. Following this, each group uploaded their homework to the part under the heading of that homework in the forum. The faculty member provided the learners with feedback after checking the homework following the due dates of that homework. The purpose was to have the learners develop the habit of cooperative learning.

\subsubsection{Weekly Opinions}

Within the scope of the formative evaluation regarding the ADDIE design model, the learners' views about their daily applications in DLP were determined on weekly basis. In line with the learners' views and their feedback, the deficiencies in relation to the teaching of the lessons, interaction factors, technical features and support factors were overcome, and the system was constantly updated in a way to make the learners satisfied with it.

\section{Conclusion, Discussion and Suggestions}

The present study aimed at transforming a course taught with traditional methods into an online course. This transformation process included online design of the course and adaptation of the ADDIE model, one of instructional design models. The related steps of the ADDIE model were adapted into online learning, and all the sub-steps were explained. Among those playing a role in the process of designing the course were instructional designers, a content expert, the faculty member and an expert on evaluation. Therefore, the whole process was conducted by the designer in coordination with the faculty member teaching the course. The necessary arrangements were done until the pilot application. The preparation of this course executed with DLP lasted about 500 hours. Following the preparation of the course, the pilot application was carried out with the learners taking the course of Programming Languages in the Summer School period. The learners were allowed to use DLP with its all aspects, and in line with their views and with the results of the usability test, DLP was revised to make the necessary changes. It could be stated that the learners were generally satisfied with DLP and agreed on its usefulness. This result supports the finding of another study that teaching with the ADDIE design model produced better outcomes than the traditional methods of instruction [56,57].

In line with the online course prepared, the following suggestions could be put forward to help online course designers:

- One of the most important deficiencies in related literature could be said to be lack of application of an instructional design model to online courses. If online course designers follow the steps of an instructional course design while developing an online course, the problems likely to be experienced will be overcome easily while teaching that course though it takes time to design an online course.

- In literature, although several studies have been 
conducted on the duration of preparing an online course, there is no related consensus. According to the curriculum applied in the Department of Computer Education and Instructional Technologies, the course of Programming Languages is taught in five class hours a week for 14 weeks. The preparation of the DLP developed for this course lasted approximately 500 hours. When the effective results obtained are taken into account, it is necessary to allocate enough time for a good-quality online course.

- The fact that online course applications present synchronous and asynchronous environments together will be important for making use of the strong aspects of the two environments.

- Online course application should be designed in a way to provide learners with social support besides educational support.

- While preparing an online course application, all the elements found in the analysis phase should be taken into consideration. Special attention should be paid especially to the needs analysis, learners' analysis, technical analysis and structural analysis.

- After preparing an online course application, conducting a pilot application will help determine and overcome the related deficiencies before the actual application.

- A strong bridge between the evaluation step and the development step in course design should be built and executed. For each problem experienced by learners in the process of taking the course, the development step should be revisited. In this way, the formative evaluation process should be completed.

- As mentioned in related studies in literature, when the degree of importance of interaction for success and satisfaction is considered, all the dimensions of interaction should be taken into account for the platform to be used for online course application.

\section{REFERENCES}

[1] Sun P, Tsai RJ, Finger G, Chen Y, Yeh D. What drives a successful e-learning? An empirical Investigation of the critical factors influencing learning satisfaction. Computer \& Education. 2008; 50: 1183-1202.

[2] Stephen DE, O'Connell P, Hall M. Going the extra mile: 'fire fighting', or laissez-faire? Reevaluating personal tutoring relationships within mass higher education. Teaching in Higher Education. 2008; 13(4): 449-460.

[3] Palloff, R. M., \& Pratt, K. (1999). Building learning communities in cyberspace: Effective strategies for the online classroom. San Francisco, CA: Jossey-Bass.

[4] Johnson L, Smith R, Willis H, Levine A, Haywood K. The 2011 Horizon Report. Austin, Texas: The New Media
Consortium; 2011 [accessed 2015-01-12]. Available at: http://net.educause.edu/ir/library/pdf/hr2011.pdf

[5] Johnson L, Adams S, Cummins M. The NMC Horizon Report: 2012 Higher Education Edition. Austin, Texas: The New Media Consortium; 2012 [accessed 2015-01-12]. Available at: http://www.nmc.org/pdf/2012-horizon-report-HE.pdf

[6] Van Der Werf M, Sabatier G. The College of 2020: Students. Chronicle Research Services; 2009 [accessed 2013-01-10]. Available at:

http://www.warren-wilson.edu/ adcommittee/Tuition_Study /2020Students.pdf

[7] Allen, IE, Seaman J. Changing Course: Ten Years of Tracking Online Education in the United States. Wellesley MA: Babson College/Quahog Research Group; 2013 [accessed 2015-12-03]. Available at: http://www.onlinelearningsurvey.c om/reports/changingcourse.pdf

[8] Bouhnik D, Marcus T. Interaction in distance-learning courses. Journal of the American Society for Information Science and Technology. 2006; 57(3): 299-305.

[9] Tello SF. An analysis of student persistence in online education. International Journal of Information and Communication Technology Education. 2007; 3(3): 47-62.

[10] Motiwalla LF. Mobile learning: A framework and evaluation. Computers \& Education. 2007; 49: 581-596.

[11] Alexander MW, Truell, AD, Zhao JJ. Expected Advantages and Disadvantages of Onlıne Learning: Perceptions from College Students Who Have Not Taken Online Courses. Issues in Information Systems. 2012; 13(2): 193-200.

[12] James G. Advantages and Disadvantages of Online Learning; 2002 [accessed 2015-01-04]. Available at: http://www.leerbeleving.nl/wbts/nieuw_basics/addis.pdf

[13] Song L, Singleton ES, Hill JR, Koh M. Improving online learning: Student perceptions of useful and challenging characteristics. The Internet and Higher Education. 2004; 7(1): 59-70.

[14] Leen E. The CAVA e-learning platform: Support for teachers. Changing Attitudes to Dating Violence, Brussels: European Council; 2013 [accessed 2015-02-02]. Available at: http://www.cavaproject.eu/sites/default/files/CAVA's\%20e-1 earning\%20portal.pdf

[15] Vonderwell S. An examination of asynchronous communication experiences and perspectives of students in an online course: A case study. Internet and Higher Education. 2003; 6: 77-90.

[16] Jaggars SS, Bailey T. Effectiveness of fully online courses for college students: Response to a Department of Education meta-analysis. Teachers College, Columbia University, Community College Research Center; 2010 [accessed 2016-02-02]. Available at: http://www.icde.org/filestore/News/20042010/2010/ResponcetoaDept.ofEducationUSAMeta-Analysi s.pdf

[17] Petrides LA. Web-based technologies for distributed (or distance) learning: Creating learning-centered educational experiences in the higher education classroom. International Journal of Instructional Media. 2002; 29(1): 69-77.

[18] Uysal Ö, Gürcan A. Assure Modeli İle Öğretim Tasarımı. 
Malatya: XIII. Conference of the International Educational Sciences, İnönü University; 2004.

[19] Durak G. The effects of a distance education programming language course on student performance. Journal of Theory and Practice in Education. 2014; 10(1): 202-219.

[20] Bernard RM, Abrami PC, Lou Y, Borokhovski E, Wade A, et al. How does distance education compare to classroom instruction? A meta-analysis of the empirical literature. Review of Educational Research. 2004; 74(3): 379-439.

[21] Driscoll A, Jicha K, Hunt AN, Tichavsky L, Thompson G. Can Online Courses Deliver In-class Results?: A Comparison of Student Performance and Satisfaction in an Online versus a Face-to-face Introductory Sociology Course. Teaching Sociology. 2012; 40(4): 312-331.

[22] Feintuch H. Keeping their distance: New study indicates students perform better online. Diverse: Issues in Higher Education. 2010; 27(3): 20.

[23] Gunawardena CN, McIsaac MS. Distance education. Handbook of research on educational communications and technology. IN: Jonassen D, editor. Mahwah: Erlbaum; 2004. p.355-396.

[24] Joy E, Garcia F. Research paper questions 'No Significant Difference' claims. Journal of Asynchronous Learning Networks. 2000; 6(1): $21-39$.

[25] Quillen I. E-learning delivery debated. Education Week. 2010; 29(30): 5.

[26] Wilson D, Allen D. Success rates of online versus traditional college students. Research in Higher Education Journal. $2011 ; 14$.

[27] Zhao Y, Lei J, Yan B, Lai C, Tan HS. What makes the difference? A practical analysis of research on the effectiveness of distance education. Teachers College Record. 2005; 107(8): 1836-1884.

[28] Borthick AF, Jones DR. The motivation for collaborative discovery learning online and its application in an information systems assurance course. Issues in Accounting Education. 2000; 15(2), 181-210.

[29] Friday E, Friday-Stroud SS, Green AL, Hill AY. A multi-semester comparison of student performance between multiple traditional and online sections of two management courses. Journal of Behavioral and Applied Management. 2006; 8(1): 66-81.

[30] Royse D. Teaching Research over the Internet: An Evaluation. Journal of Teaching in Social Work. 2000; 20(1): 145-158.

[31] Gagne M, Shepherd M. Distance Learning in Accounting: A Comparison Between a Distance and Traditional Graduate Accounting Class. T.H.E. Journal. 2001; 28(9): 58-65.

[32] Huh S, Yoo S, Jin J, Lee K. Comparisons of performances between online learners and offline learners across different types of tests. Academy of Information and Management Sciences Journal. 2008; 11(1): 45-63.

[33] Piccoli G, Ahmad R, Ives B. Web-based Virtual Learning Environments: A Research Framework and a Preliminary Assessment of Effectiveness in Basic IT Skills Training. MIS Quarterly. 2001; 25(4): 401-26.
[34] Rich, AJ, Dereshiwsky MI. Assessing the Comparative Effectiveness of Teaching Undergraduate Intermediate Accounting in the Online Classroom Format. Journal of College Teaching \& Learning. 2011; 8(9): 19-28.

[35] Roseth CJ, Saltarelli AJ, Glass CR. Effects of face-to-face and computer-mediated constructive controversy on social interdependence, motivation, and achievement. Journal of Educational Psychology. 2011; 103(4): 804-820.

[36] Russell TL. The no significant difference phenomenon. Montgomery, AL: International Distance Education Certification Center; 1999.

[37] Aly İ. Performance in an Online Introductory Managerial Accounting Course in a Classroom Setting. Canadian Journal of Higher Education. 2013; 43(2): 85-99.

[38] Cavuş N, Uzunboylu H, Ibrahim D. Assessing the success of students using a learning management system and together with a collaborative tool in web-based teaching of programming languages. Journal of Educational Computing Research. 2007; 36 (3): 301-321.

[39] Daymount T, Blau G. Student performance in online and traditional sections of an undergraduate management course. Institute of Behavioral and Applied Management. 2008; 9(3): 275-294.

[40] Farag W. Comparing Achievement of Intended Learning Outcomes in Online Programming Classes with Blended Offerings. SIGITE Conference; Calgary, Alberta: Mount Royal University; 2012. p. 25-30.

[41] Jones KT, Chen CC. Blended learning in a graduate accounting course: Student satisfaction and course design issues. The Accounting Educator's Journal. 2008; 18: 15-28.

[42] Köse U, Koç D, Yücesoy SA. Design and development of a sample "computer programming" course tool via story -based e-learning approach. Educational Sciences: Theory \& Practice. 2013; 13(2): 1235 - 1250.

[43] Lapsley R, Kulik B, Moody R, Arbaugh J. Is Identical Really Identical? An Investigation of Equivalency Theory and Online Learning. The Journal of Educators Online. 2008; 5(1): 1-19.

[44] Stivason T, Saunders G, Price J. A comparison of student performance in an online introductory accounting course with traditional classroom students. College Teaching Methods \& Styles Journal. 2008; 4(5): 1-8.

[45] Doğan D, Tüzün H, Dağhan G, Altıntaş A, Ilgaz H, et al. Uzaktan Eğitimde Ders Tasarımı: Yüz Yüze Verilen Bir Dersin Uzaktan Eğitim Sürecine Hazır Hale Getirilmesi. e-journal of new world sciences academy. 2012; 7(2).

[46] Durak G. The online teaching of programming languages: Examining learner's attitudes, satisfaction and success. [Unpublished doctoral dissertation]. Anadolu University, Institude of Social Sciences; 2013.

[47] Vejvodova J. The ADDIE Model: Dead or Alive?. 2009 [accessed 2014-04-19]. Available at: http://virtuni.eas.sk/rocnik/2009/pdf/paper_127.pdf

[48] McKeachie WJ. Research on College Teaching: The Historical Background. Journal of Educational Psychology. 1990; 82(2): 189-200. 
[49] Spahn K. Class Size and Faculty Effectiveness and Quality. 39th Annual Institutional Research Forum, Seattle: WA; 1999.

[50] Oestmann E, Oestmann J. Relationship between online class size and student discussion interactivity. Journal of Online Educators. 2005; 1(4): 16-32.

[51] Keller J. Using the ARCS Motivational Process in Computer-Based Instruction and Distance Education. New Directions for Teaching and Learning. 1999; 78: 39-47.

[52] Bilgiç EŞ. E-öğretim Tasarım Süreci: Bir Materryalin Kullanışlığına İlişkin Katılımcı Görüşleri. [Master's thesis]. Ankara: Türkiye Cumhuriyeti Merkez Bankası İnsan Kaynakları Genel Müdürlüğü; 2005.

[53] Moore M. Three types of interaction. The American journal of distance education. 1989; 3(2): 1-6.

[54] Holmberg B. Theory and practice of distance education. London, New York: Routledge; 1995.

[55] Bunn J. Student persistence in a LIS distance education program. Australian Academic Research Libraries. 2004; 35(3): 253-270.

[56] Wang Pao-hsi. The production of reusable learning objects in Chinese culinary arts online instruction using the ADDIE instructional design model. [dissertation]. Pocetello: Idaho State University; 2011.

[57] Zimmerly LC. Dance Online: Can the Students Still Follow the Steps? A Rationale for Online Delivery Methods in Dance. [dissertation]. Pocatello: Idaho State University; 2012. 0 